\title{
Perception of Adolescents About Intrusive Advertising at Telkomsel Providers and XL Axiata
}

\author{
Yoga Dwi Ramadika ${ }^{1}$, Puji Lestari ${ }^{2}$, Isbandi Sutrisno ${ }^{3}$ \\ 1,2,3 Program studi Ilmu Komunikasi, Fakultas Ilmu Sosial dan Ilmu Politik \\ Universitas Pembangunan Nasional "Veteran" Yogyakarta, \\ Jl. Babarsari 2, Tambakbayan, Yogyakarta 55281, Indonesia \\ E-mail: yogadwiramadika13@gmail.com ${ }^{1}$; puji.lestari@upnyk.ac.id ${ }^{2 *}$; isbandi_sutrisno@yahoo.com ${ }^{3}$ \\ *corresponding author
}

\begin{abstract}
This research aims to find out the perception and decision-making of consumers related to intrusive advertising in Telkomsel and XL Axiata providers among Yogyakarta teenagers. This research uses qualitative descriptive methods by conducting observations, in-depth interviews with Telkomsel and XL Axiata provider users, and documentation of examples of intrusive advertising. The results of this study found that the perception of provider users could be positive and negative perceptions of intrusive advertising. Provider user perception is divided into three categories: The first category is the provider user who does not care about intrusive advertising. The second is the user of the provider who is disturbed by the intrusive advertising and continues to use the provider. Third, the user of the provider who is very disturbed by the intrusive advertising and replaces the provider with another. These perceptions can influence decision-making to use the provider. This research contributes in the form of advice to providers to follow the ethics of Indonesian advertising so as not to interfere with the convenience of users while browsing. Keywords: Intrusive Advertising; Perception; Provider Telkomsel; Provider XL Axiata
\end{abstract}

\begin{abstract}
Abstrak
Penelitian ini bertujuan untuk mengetahui persepsi dan pengambilan keputusan konsumen terkait intrusive advertising pada provider Telkomsel dan XL Axiata di kalangan remaja Yogyakarta. Penelitian ini menggunakan metode deskriptif kualitatif dengan melakukan observasi, wawancara mendalam kepada pengguna provider Telkomsel dan XL Axiata, dan dokumentasi contoh intrusive advertising. Hasil penelitian ini menemukan bahwa persepsi pengguna provider dapat berupa persepsi positif dan negatif terhadap intrusive advertising. Persepsi pengguna provider terbagi menjadi tiga kategori: Kategori yang pertama adalah pengguna provider yang tidak peduli dengan adanya intrusive advertising. Kedua adalah pengguna provider yang merasa terganggu dengan adanya intrusive advertising dan tetap menggunakan provider tersebut. Ketiga, pengguna provider yang merasa sangat terganggu dengan adanya intrusive advertising dan mengganti providernya dengan yang lain. Persepsi tersebut dapat memengaruhi pengambilan keputusan untuk menggunakan provider tersebut. Penelitian ini berkontribusi berupa saran kepada penyedia untuk mengikuti etika periklanan Indonesia agar tidak mengganggu kenyamanan pengguna saat browsing. Kata kunci: Iklan yang Mengganggu; Persepsi; Penyedia Telkomsel; Penyedia XL Axiata
\end{abstract}

\section{Introduction}

In today's digital age, advertising on internet media is one of the strategies that is suitable for providing information about products or used to increase brand awareness. Advertising is present in order to win the competition against the dominance of competitors in the fight over consumers, so that many ads are often raised to attract attention (Lukitaningsih, 2013). Ads that appear in product promotions become annoying to users. The case that has been widely discussed since 2014 is about two large producers of cellular service providers namely Telkomsel and XLAxiata. Conscious or not, consumers or users of the two providers will be more often exposed to transitional advertisements when opening a website or sites in their mobile phone browser. The advertising practice is intrusive advertising or commonly referred to as a transition ad from a mobile operator on a mobile phone. This 
advertisement appears when mobile phone users want to open internet links on mobile phone devices (OJS Unud, Agung, 2017).

As consumers, because they are constantly fed by exposure to advertisements when opening a link on the browser in their mobile phone, they will certainly feel uncomfortable. If the inconvenience is received continuously or with the increasing intensity, then slowly the ad will make consumers no longer comfortable and make a bad impression on the product even, can destroy trust in the product. This is following research by Faziza and AB (2017) which states that most of the respondents' level of adverts in applications on smartphones leads to negativity and tends to dislike the exposure of existing advertisements when the responsiveness operates the smartphone. For this reason, regulations are needed to regulate ethics in advertising so consumers are not disturbed by the advertisements presented.

Even quoted from beritasatu.com page, at least six Digital Advertising Development Associations have asked Telkomsel and XL to stop the practice of intrusive advertising that inserted on the association's website. The six associations are Indonesia E-commerce Association (IDEA), Indonesia Digital Association (IDA), Indonesian Internet Service Providers Association (APJII), Indonesian Domain Name Managers (Pandi), Association of Asia Pacific Advertising Media (AAPAM), and Company Unity Indonesian Advertising (PPPI).

This practice is considered unethical and violates intellectual property rights (HAKI), as well as violating Law No. 11/2008 concerning Information and Electronic Transactions (ITE) and Law No. 8/1999 concerning Consumer Protection. From research related to intrusive advertising, Rufaida (2017) has shown that the display of inappropriate intrusive advertisement advertisements is not in accordance with the laws and regulations and Ethics of Pariwara Indonesia. The right of consumers to reject intrusive advertisements is based on Article
18 paragraph (1) of Law Number 8 of 1999 concerning Consumer Protection. This avoids consumers from being a weak party in a contract and equalizing the position of both parties. The productive age group is the most internet users in Indonesia. According to a survey of the Indonesian Internet Service Providers Association (APJII), almost half of the total internet users in Indonesia are people in the 1934 age group (49.52\%). While the second largest user is the age group $35-54(29.55 \%)$, the age group $13-18$ years $(16.68 \%)$, and users with age above 54 years (4.24\%). (www.katadata.co.id).

In this study the authors using The Intrapersonal Theory. Where intrapersonal communication can be interpreted as communication that occurs within yourself. This is an internal dialogue and can occur even with other people. This context also includes when we imagine, perceive, daydream, and resolve problems in our heads (West and Turner, 2008; 34). The process of processing information on intrapersonal communication includes sensation, perception, memory, and thinking. In this study using one of the information processing processes, namely perception.

Perceptionis the experience of objects, events, or relationships, which are obtained by deducing information and interpreting messages (Rohim, 2009: 59-60). Perception can also be said as a process of organizing and interpreting sensory impressions to give meaning to the environment (Budiono, 2013). Perception of an object can be different from others because of three perceptual processes, namely attention, interference, and selective recall. Perception can be interpreted as the conclusion of information received by the senses of an object or event. Through the senses, humans can obtain information or knowledge and understand the physical quality of their environment. Perception is a view or assessment of a stimulus after a sensation. Perception is influenced by three factors (Sukendar 2017: 39), there are: (1) Attention Factor, which occurs 
if a person concentrates on one sense device. Attention factors are determined by external factors (movement, intensity, and novelty) and internal (biological and sociopsychological). (2) Functional Factors, derived from needs, experiences, past and things that include personal factors. What determines perception is not the type or form of stimulus, but the characteristics of the person who responds to the stimulus. (3) Structural factors that originate solely from the nature of physical stimuli and the neurological effects they cause on the individual's nervous system. Or it can be interpreted as environmental influences on the way individuals interpret stimulants, and stimulant properties.

In this study, the researcher connected this phenomenon with the perception of adolescents as consumers or users of both providers. Perception is the process of how individuals become aware of the many stimuli that affect the individual's senses. Perception influences stimuli (stimulus) or the message of what we absorb and the meaning of what we give to them when they reach consciousness (Rohim 2009: 60). The stimulus referred to is the exposure of intrusive advertising(serobot) that is done by both providers when it opens a link on its mobile phone. This is similar to provider users who initially feel normal when opening a link on their mobile phone, but when there is a transition ad, the perception of the user will change about the provider. This is following Wali's research (2017) which states that the more consumers feel that advertisements that appear on smartphones disturb the comfort (intrusive), the higher the feeling of anger (irritation) that appears on smartphone users. Consumer anger harms the formation of attitudes on Adsense Mobile and advertised products.

Another similar study was conducted by Said and Nor (2010), the results of the study stated that the respondents below 20 years of age have a low interfere perception of advertisement, thus the high percentage of $47.9 \%$. The respondents between 30 to 39 years of age perceived SMS ad as highly interfering at $40.8 \%$. The age group of 40 to 49 years old was divided almost equally with $39.7 \%$ perceived SMS ad as low in its interfering dimension and the other $42.9 \%$ perceived it as highly interfering. Surprisingly the perception level of the respondents within the age group of above 50 years old is moderately interfering at $50 \%$. The same study was conducted by Hariningsih and Munarsih (2014) which stated that the perception of goal avoidance had a positive and significant effect on internet advertising avoidance. However, negative perceptions of past experiences and chaos perceptions are not significant for the avoidance of internet advertising.

This is what later became a concern for researchers to carry out this research. This study aims to determine the perceptions and decision-making of consumers regarding intrusive advertising at Telkomsel and XL Axiata providers among teenagers in Yogyakarta.

\section{Consumer Behavior}

Consumer behavior is describing how consumers make purchasing decisions and how they use and regulate the purchase of goods or services (Lamb, et al. 2009: 188). Consumer behavior is an activity carried out by individuals to assess products and services, whether they are suitable or not with the needs they want. According to Lamb, consumer behavior is influenced by four factors, namely: Culture, Social, Personal, and Psychological (2009: 201). In psychological factors, a person's purchasing decision is influenced by four main factors, namely motivation, perception, knowledge, beliefs and attitudes.

This study discusses consumer perceptions of intrusive advertising carried out by Telkomsel providers and XL Axiata, where individuals can perceive things with different points of view according to the characteristics of the individual itself. The presence of intrusive advertising is interpreted as an external stimulus. 
How all messages or stimuli are managed so that thoughts or perceptions arise about an event which then influences decision making.

\section{Research Methods}

This study uses a qualitative descriptive research method. The object of this research is intrusive advertising meanings received by users of Telkomsel and XL Axiata providers. The subjects of this study were six (6) teenagers, each provider consisting of three (3) people. Data collection techniques were carried out by researchers' observations of providers, in-depth interviews with research subjects about providers, and documentation in the form of pictures or diagrams. The data analysis technique is done by identifying and evaluating the data frominterviews and observations. The data is chosen according to the needs of researchers, then presented in the form of a picture of a diagram of perceptions that produce conclusions. The resulting conclusions are describes comprehensively the perceptions of adolescents about intrusive advertising at Telkomsel and XL Axiata providers.

\section{Results of Research and Discussion}

This research was conducted in the period from September to October 2018, there were 3 Telkomsel provider users and 3 XL Axiata users with the age-susceptible adolescents from the age of 19-24 years. This study explains how the perceptions of users (users) related to intrusive advertising on Telkomsel and XL Axiata providers, as well as their influence on decision making. This study uses the theory of intrapersonal communication which is communication that occurs within a person. This includes the time when someone imagines, perceives, daydreaming and solving problems in his head. One of the information processing processes of intrapersonal communication theory includes sensation, perception, memory, and thinking, namely perceptions of intrapersonal communication theory. Perception can be formed by the presence of stimulants which are then accepted by one's senses differently. The acceptance of different stimulants is then interpreted by individuals based on the factors of attention, experience, and environment they receive. Then the stimulant that is received by individuals will be processed through intrapersonal communication and arises of thought or perception of the stimulant.

Perception was chosen because it was deemed appropriate to help researchers discuss the research "consumer perceptions about intrusive advertising providers Telkomsel and XL Axiata". Perception in this research is used to see the process of provider users in interpreting intrusive advertising at the beginning of opening a web browser, to produce an action in the form of still using the provider or even changing the provider. Therefore, researchers use perceptions to see the decision making by users of these providers.

The researcher divides into three categories based on perceptions arising from the user towards the existence of intrusive advertising. The first category is provider users who don't care about intrusive advertising. Provider users who do not care about intrusive advertising argue that this is not considered a bother because the ad can still be closed. The second category is the user provider who feels annoyed with intusive advertising but still uses the provider. Users feel disturbed because the ads that appear cover all web pages that will be addressed, then users still continue to use the provider because it is more concerned with speed. The third category is provider users who feel very disturbed by the presence of intrusive advertising to replace the provider. Users feel very disturbed because the advertisement is hindering work and making it uncomfortable, which indirectly forces users to enter the ad's webpage.

From the results of the research that has been described the researchers found that perceptions that arise after users see or are exposed to intrusive 
advertising are divided into two, namely positive and negative perceptions. Positive perception arises because intrusive advertising can still be closed and indirectly internet users will remember what products are advertised at the intrusive advertising. Negative perceptions arise because of the nature of these advertisements that disrupt and cover all web pages that will be addressed so that it inhibits the user's freedom in getting information. Some provider users have the perception that intrusive advertising when opening a web browser is a bother. Perception of intrusive advertising is considered as something that is disturbing and can influence decision making to choose a provider. Researchers describe the perceptions of provider users influenced by three factors, namely attention factors, functional factors, and structural factors.

The attention factor that determines perception occurs when someone concentrates on one of his sensory devices, and excludes input from other sense devices. The results of the study show that provider users focus on intrusive advertising through the eye which then takes place in a visual process where the process produces judgment and meaning. The assessment produced by each individual can vary.

The attention factor is divided into two, namely external factors that attract attention and interesting internal factors of attention. The results show that the external factors that attract attention are the movement and intensity of stimuli that attract the attention of provider users. Provider users pay attention to prominent stimuli from intrusive advertising, namely in the form of advertisements that suddenly appear and cover all web pages that are intended. The movement of an advertisement image that suddenly appears can highlight the object so that the ad becomes a concern, coupled with the color of the ad that contrasts with the background of the webpage to be accessed.

Internal factors that influence attention are biological factors, in this study there are all mind users of the provider dominated by the desire of users of users to get information or news quickly, so stimuli such as intrusive advertising that appears when opening a web browser becomes a disturbing thing. Intrusive advertising when opening the web on mobilephone was a factor of concern for provider users, because it was considered to attract attention with contrasting size and color. According to respondents, advertisements that suddenly appear and cover all web pages with contrasting colors are considered to interfere with vision and freedom in finding information.

The second factor that determines perception is functional factors. Functional factors are factors that come from needs, experiences, past and things that include personal factors. Past experience of provider users who have used other brand providers has made it supportive to use Telkomsel and XL Axiata providers. Internet comfort and speed are things that must be owned by a provider, because the speed of the internet has become a necessity in getting information or completing work. Needs can also be a supporting factor for someone to use the provider.

The third factor that determines perception is structural factors. Structural factors are factors that originate solely from the nature of physical stimuli and the neural effects that are generated on the individual nervous system. That is, there is an influence from the nature of the stimulant itself on the way individuals interpret a stimulant. The influence of these stimulants which then makes the individual perceptions form attitudes or actions to choose a provider. stimulant in this study is intrusive advertising.

Attitudes or actions will definitely appear when someone looks at intrusive advertising and means whether the advert is annoying or not. The actions of provider users who do not care about the existence of intrusive advertising are to immediately close the ads that appear by pressing the close (x) image located in the upper right corner of the ad and continuing to open the web to be accessed. 
The action taken by the provider of the user who is bothered is to try to close the ad, on the close $(\mathrm{x})$ button located in the upper right corner of the ad. If it cannot be closed the respondent tries to avoid the ad by opening a new page. The actions taken by provider users who feel very disturbed by the presence of intrusive advertising is to immediately close the ad by pressing the close ( $\mathrm{x}$ ) button located in the upper right corner of the ad and often the button cannot be used. If the button cannot be used, the respondent tries to open a new link.

According to the UPN Communication Psychology lecturer, Edwi Arif stated that psychologically humans have a high sense of curiosity, when someone knows that intrusive advertising is annoying but because of curiosity and curiosity, someone will still open the web browser. This is called cognitive dissonance, where a person will continue to do something wrong, but he believes something is right. $\mathrm{He}$ believes that intrusive advertising is a disturbing thing, but he still uses the provider.

Provider users who do not care about intrusive advertising say they do not want to change the provider, it is because the ad has not bothered him because he can still be closed and he is still comfortable with the provider. Provider users who feel disturbed by intrusive advertising state that they do not want to change the provider, this is because respondents are more concerned with speed even though the adverts interfere with their flexibility in finding information and news. While provider users who are very disturbed by the presence of intrusive advertising state that they have been very disturbed by the ad, and have changed the provider because it is considered to be very disturbing. Intrusive advertising is considered very disturbing because it is considered to be an obstacle in getting information and completing work.

According to the UPN Communication Psychology lecturer, Edwi Arif stated that perceptions can influence decision making because perceptions are on someone's cognitive if he knows that intrusive advertising is a disturbing thing but he likes the provider so he will still use it. Positive perception can cause affective feelings or positive emotions. One's perception can influence decision making because one's decision making process is influenced by psychological factors. Someone recognizes their feelings, collects and analyzes information, form thoughts and opinions to take action. A person's purchase decision is influenced by four main psychological factors, namely motivation, perception, knowledge, beliefs and attitudes.

The perception of provider users who do not care about intrusive advertising is that the ad does not bother him, but annoys people who need fast information or news. Provider users who feel disturbed by the existence of intrusive advertising have the perception that intrusive advertising is a disturbing thing if it covers all the web pages that will be targeted and has not yet wanted to change the provider. While provider users who are very disturbed by the existence of intrusive advertising have the perception that advertisements that appear suddenly and cover all web pages to be addressed are very disturbing. This can affect the willingness of respondents to change providers and now the respondent has changed the provider.

According to the UPN Communication Psychology lecturer, Edwi Arif stated that intrusive advertising is interpreted differently in each individual because one's perception must be preceded by experience. That experience causes a person to continue the perception and someone is interpreting the message conveyed. To facilitate the discussion, the researchers made a chart like Figure 1:

After provider users see intrusive advertising continuously when opening a link on a web browser, different perceptions will emerge from each person. This perception provides an assessment and view of the provider, whether the user is satisfied with the service provided by the provider or not. From the research results, users 


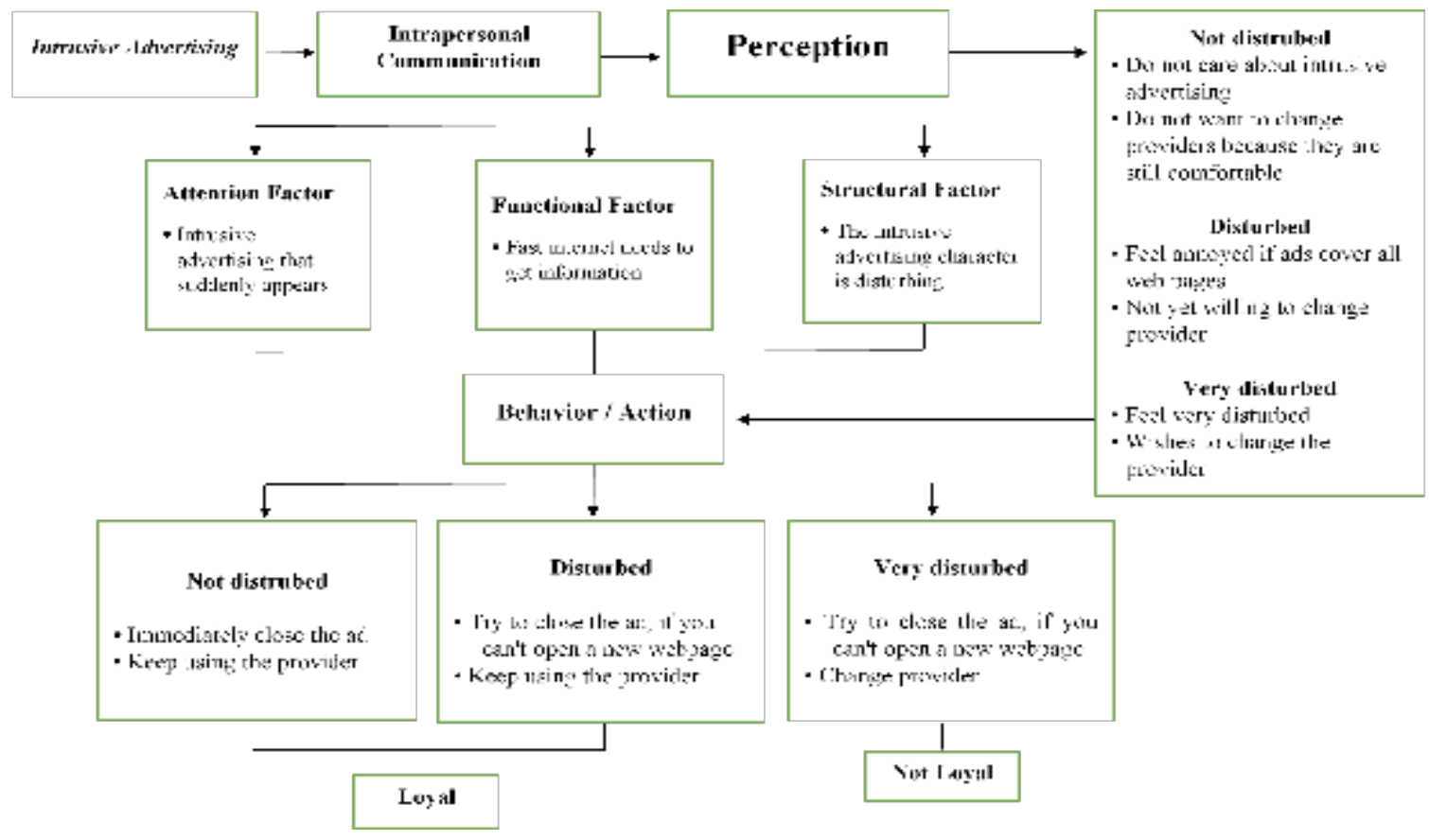

Figure 1. Discussion Flow Diagram

Source: Researcher Document (2018)

feel satisfaction from the internet speed provided by Telkomsel providers and the relatively low prices from XL Axiata providers. Satisfaction is what makes Telkomsel and XL Axiata provider users make repeat purchases or can be said to be loyal to the provider, even though there are many advertisements that interfere with users accessing information on their web browser.

This loyalty can be seen from the length of time the respondent uses a provider that has been chronic. Although provider users still get inconveniences, shortcomings and disruptions caused by intrusive advertising. User loyalty to the product can be lost when the customer or user does not trust the provider. Services that tend to decline as perceived by respondents in the very disturbed category are what cause loyalty to the product to be lost. Respondents were disappointed with the presence of intrusive advertising when opening a web browser that disrupted the freedom to access the internet and the services received were not worth the relatively expensive price.
The concept of the relationship between user attitude and the number of advertisements that appear can cause resentment in the user. This is similar to Intrapersonal Theory (Dharma, 2017), which is communication with oneself, where the study is still considered too subjective and cannot be known by others or judged in general. This frustration is communicated with oneself due to advertisements that appear. This affects the user's attitude, if the user is positive in dealing with it, then the user still uses it without any frustration in the heart. Conversely, annoyed and negative users might not use the provider (Darda \& Premananto, 2015).

The provider should be able to consider placing advertisements in places that do not interfere with the freedom of internet users in getting information. The provider is also guided by the Indonesian Advertising Ethics which reads that advertisements may not be displayed in such a way as to interfere with the ability or freedom of the public to browse and interact with related sites unless previously warned. 


\section{Conclusion}

Provider users can be divided into three categories after seeing intrusive advertising. The first category is provider users who do not care about intrusive advertising. Second, provider users who feel disturbed by the existence of intrusive advertising and continue to use the provider. Third, provider users who feel very disturbed by the existence of intrusive advertising and changing providers with others.

Providers' perceptions of intrusive advertising at the beginning of opening a link on a web browser in the form of a positive and negative perception. The user considers the positive perception because the ad can still be closed and negative perceptions arise because the ad is annoying and suddenly appears to meet the webpage to be addressed. Provider users who do not care and are not disturbed by the presence of intrusive advertising perceive that the ad is not an annoying thing so that users continue to use the provider, on the other hand provider users who are not bothered argue that intrusive advertising can interfere with users who want to get information quickly. Provider users who feel disturbed by the presence of intrusive advertising perceive that the advert is disturbing because the advertisement appears to cover all the web pages that will be addressed, but the user still uses the provider because it has gained satisfaction from internet speed. Provider users who feel very disturbed by the presence of intrusive advertising perceive that the ad is very annoying because the advertisement is preventing users from accessing information and making it uncomfortable. This negative perception is what makes provider users decide not to use the provider.

Perception can influence someone's purchasing decisions because a person's decision-making process is influenced by psychological factors namely motivation, perception, knowledge, beliefs and attitudes. Someone will recognize and interpret their feelings, collect and analyze information, form thoughts and opinions to take action to buy. This research contributes in the form of suggestions to the provider to be guided by the Indonesian Advertising Ethics so as not to interfere with the user's comfort when browsing.

\section{References}

Agung, Kepakisan. CD Dahana. (2015). Periklanan Intrusive advertising / Iklan Peralihan Pada Mobile phone, p.1. Available at https://ojs.unud.ac.id/index.php/ kerthasemaya/article/view/29871/18388 (diakses tanggal 10 Juli 2018)

Budiono, F. L. (2013). Persepsi dan Harapan Pengguna terhadap Kualitas Layanan Data pada Smartphone di Jakarta. Buletin Pos Dan Telekomunikasi, 11(2), 93-108.

Darda, D. M., \& Premananto, G. C. (2015). Pengaruh Perceived Deception Dan Kredibilitas Perusahaan Terhadap Sikap Dan Niat Seseorang Mengikuti Undian Berhadiah. Jurnal Manajemen Teori dan Terapan| Journal of Theory and Applied Management, 8(2).

Dharma, F. A. (2017). Dialektika Komunikasi Intrapersonal: Mengkaji Pesona Komunikasi Dengan Diri Sendiri. Al-Balagh: Jurnal Dakwah dan Komunikasi, 2(1), 25-44.

Fazizah, A., Sos, S., \& AB, M. (2017). Analisis Faktor-Faktor Yang Mempengaruhi Tingkat Adopsi Pengguna dan Efektivitas Terpaan Iklan Dalam Aplikasi Sebuah Smartphone. Jurnal Heritage, 5(1), 25-42.

Hariningsih, E., \& Munarsih, E. (2014). Analisis perilaku penghindaran iklan internet oleh konsumen. Jurnal siasat bisnis, 18(2), 180189.

https://databoks.katadata.co.id/ datapublish/2018/02/23/usia-produktifmendominasi-pengguna-internet (access date 10 July 2018)

Lamb et al. (2009). Manajemen Pemasaran. Jakarta : Salemba Empat

Lukitaningsih, A. (2013). Iklan yang efektif 
sebagai strategi komunikasi pemasaran. Jurnal Ekonomi Dan Kewirausahaan, 13(2), 116-129.

Rufaida. (2017). Tinjauan yuridis perlindungan hukum bagi pengguna layanan mobile internet sebagai konsumen tehadap iklan peralihan (intrusive advertisment) ditinjau dari peraturan perundang-undangan. Available at https://repository.maranatha. edu/22985/ (access date 6 November 20118) Rohim, Syaiful. (2009). Teori Komunikasi: Perspektif, Ragam dan Aplikasi. Jakarta: PT Rineka Cipta.
Said, M. B., \& Nor, S. M. (2010). The Perception of SMS Advertising Intrusiveness Differs Between Age Group. Journal of Management and Business, 9(2).

Sukendar, Markus Utomo. (2017). Psikologi Komunikasi: Teori dan Praktik. Yogyakarta: CV Budi Utama

Wali, M. (2017). Adsense Mobile dan Respon Pengguna Smartphone: Intrusiveness dan Irritation. Jurnal EMT KITA, 1(2), 107-120.

West, Turner. (2008). Pengantar Teori Komunikasi Analisis dan Aplikasi. Jakarta. Salemba Humanika. 